\title{
Effect of Effective Management of Donors' Fund on ICT Sector Development in Rwanda
}

\author{
Jean Bosco Harelimana ${ }^{1, *} \&$ Vancon Dusengimana ${ }^{1}$ \\ ${ }^{1}$ Institut d'Enseignement Superieur de Ruhengeri, Musanze, Rwanda \\ *Correspondence: Institut d'Enseignement Superieur de Ruhengeri, P.O.B. 155 Musanze, Musanze, Rwanda. E-mail: \\ harelijordan@yahoo.fr
}

Received: September 5, 2018

Accepted: September 25, 2018

Online Published: October 13, 2018

doi: $10.5430 / \operatorname{mos} . v 5 \mathrm{n} 4 \mathrm{p} 13$

URL: https://doi.org/10.5430/mos.v5n4p13

\begin{abstract}
The main objective of this paper is to assess the effect of effective management of donors' fund on ICT sector development in Rwanda.

A Purposive sampling have been used to select employees in charge of ICT in higher learning institutions, Broadband Systems Corporation Ltd (BSC Ltd) staff, Rwanda Information Society Authority (RISA) staff , MINECOFIN projects implementation unit staff and Rwanda Development Board single project implementation unit staff. In total 24 employees from these institutions contributed to this research through responding elaborated questionnaire and by the mean of interview. Purposively six students responded to the questionnaire.

The questionnaire and an interview guide were used to collect primary data and were analyzed using Statistical Package for Social sciences, descriptive and inferential statistics were adopted as research approach. Qualitative data was treated through sound content analysis.

Results from the research found the following: It has been observed that the total budget of USD 24.M allocated to finance the Rwandan ICT sector was executed up to $99.54 \%$ and all components have been implemented at a satisfactorily rate by both the World Bank and the Government of Rwanda. This high finance performance rate caused a radical change in ICT Sector development whereby after the project implementation period elapsed, a number of ICT sector development indicators proved a tremendous shift. One of those indicators is mobile subscriptions and internet subscriptions that increased $217 \%$ and 1,000\% respectively. The cost of international internet connectivity got an up-down shift from $\$ 10,000$ in 2008 up to $\$ 125$ in 2014 . Both physical and financial project implementation indicators evidenced the close relationship or the causality of ICT sector development given an effective funds management. Finally, the Pearson coefficient of $0.814^{* *}$ that was obtained from testing both variables of this study resulted in positive high correlation between donors' funds management and the ICT sector development.
\end{abstract}

Keywords: donors' fund, information communication and technology

\section{Introduction}

Donors' fund or foreign aid for the purpose of this study is financial flows, technical assistance, and commodities designed to promote economic development and welfare as their main objective and they are provided as either grants or subsidized loans (Randhawa, 2012).

According to Randhawa (2012) foreign aid or donors' fund are most of the time bilateral or multilateral aid. He indicated that bilateral aid is when one country provides a grant or loan to another country. He continue to indicate that multilateral aid, when loans or aid is provided by international agencies such as World Bank, International Finance Corporation, IMF, International Development Agency, Asian Development Bank, Islamic Development Bank, Pakistan Development Forum and so on.

In fact, donors' fund contributes towards three things: to make available additional supplies of foreign exchange, to supplement domestic savings and to facilitate transfer of technology (Goswami, 2016)

In recent years, donors fund for the ICT sector has shifted from financing infrastructure to providing assistance for 
ICT policy and regulatory frameworks and IT capacity building. Some donors, such as the World Bank and the African Development Bank, are increasingly financing the development of applications for mobile phones, including for the health sector. Donors generally combine a two-pronged approach for promoting ICT in Least and Middle Income Countries (LMICs) that is based on targeted intervention for the ICT sector (e.g. financing broadband infrastructure, support to IT-based industries), and mainstreaming of ICTs in priority sectors (Delponte, Grigolini, Moroni, Vigneti, Claps \& Giguashvili, 2015).

ICT is considered as an engine of economic growth. It affects it in two ways, directly via the ICT producing sectors and indirectly through the sectors called users. All economic sectors are or become users of ICT to the extent that indirect productivity gains related to digitization and the way it is used are often seen as the main vector of growth in the developed economies (Mefteh \& Benjassen, 2015).

Since 2000 the Government of Rwanda (GoR) has established institutions and mechanisms to create an enabling environment for ICT development, deployed critical world-class infrastructure and is continuously developing a skilled human resource base in its quest to become a knowledge-based society and regional ICT hub (MYICT b, 2015).

Rwanda strives to leverage ICTs in all sectors of the economy and is registering tremendous progress. In 2007, Rwanda took a key step toward its long-term goal when it became the 1st East African country and the 3rd in Africa to adopt the "One Laptop per Child" program. This initiative aims to provide pupils with laptops in order to bridge the global digital divide (MYICT b, 2015).

In 1998, the Rwandan ICT for Development (ICT4D) policy was adopted in five key priority sectors (governance, education, health, agriculture and business and finance). ICT4D was adopted to implement policies and plans that would address Rwanda's developmental challenges in the information and technology age, in order to accelerate the country's socio-economic development (MYICT a, 2015).

To improve ICT sector, in 2008 Rwanda has signed agreement with International Development Association (IDA) to finance the phase two of Regional Communications Infrastructure Program (RCIP) Rwanda project. The objectives of the Project are to contribute to lower prices for international capacity and extend the geographic reach of broadband networks in the Recipient's territory (World Bank, 2008).

However though foreign aid has continued to play an important role in developing countries, especially sub-Sahara Africa Rwanda included, it is interesting to note that after half a century of channeling resources to the Third World, little development has taken place. In almost all of sub-Saharan Africa, there is a high degree of indebtedness, high unemployment, absolute poverty and poor economic performance (Afande, 2013).

The ineffective use of donors' fund in developing countries has been affirmed by Njeru (2003) that impacts of foreign aid on savings and growth in developing countries, besides having made a good case for increased flow of foreign aid, raise questions on the utilization of these funds on their designated projects. The donor community has become increasingly concerned that part of the development assistance intended for crucial projects finances projects other than those earmarked for funding

The main focus of this study is to profoundly analyze and find the effects of donor's funds management on the ICT sector development in Rwanda, as a case study of RCIPRW.

\section{Objectives}

The main objective is to assess the effect of effective management of donors' fund on ICT sector development in Rwanda, the specific objectives are:

To evaluate the indicators of donors' fund management in context of RCIP Rwanda project.

To assess the determinants of ICT development before and after the completion of RCIP Rwanda project.

To assess the relationship between indicators of donors' fund management and determinants of ICT development of RCIP Rwanda project.

\section{Literature Review}

Hossain (2014) conducted a research on the effect of foreign aid on the economic growth of Bangladesh. The findings revealed that Foreign aid variable has positive sign in all cases, indicating that foreign aid has positive effect 
on the economic growth of Bangladesh. This coefficient is statistically significant in two cases out of four cases. It is not found statistically significant for the entire period 1980-2012. This result is consistent with data. The data shows that Foreign Aid has the on average 7.38 percent contribution in GDP of Bangladesh in 1980s. While this figure positively declining in the last two decades and recorded as average 4.05 percent and 1.8 percent of GDP in 1990s and 2000s respectively.

Ekanyake and Chatrna (2010) have conducted a research on the effects of foreign aid on the economic growth of developing countries. The study used annual data on a group of 85 developing countries covering Asia, Africa, and Latin America and the Caribbean for the period 1980-2007. The major point emerging from this work is that foreign aid has a mixed impact on economic growth of developing countries. First, when the model was estimated for different time periods, foreign aid variable has a negative sign in three out of four cases, indicating that foreign aid appears to have an adverse effect on economic growth in developing countries. In addition, this coefficient is not statistically significant in any of the four cases. Second, when the model was estimated for different regions, foreign aid variable has a negative sign in three out of four cases, indicating that foreign aid appears to have an adverse effect on economic growth in developing countries. However, this variable is positive for African region indicating that foreign aid has a positive effect on economic growth in African countries. This is not surprising given that Africa is the largest recipient of foreign aid than any other region. Finally, when the model was estimated for different income levels, foreign aid variable has a positive sign in three out of four cases, indicating that foreign aid appears to have a positive effect on economic growth in developing countries. However, this variable is negative for low-middle income countries indicating that foreign aid has a negative effect on economic growth in these countries. Thus, the findings of this study are, for the most part, consistent with findings of previous studies on theeffects of foreign aid on economic growth.

Abouraia (2014) has analyzed the impact of foreign aid in economic development of developing countries with a case of Philippine. The researcher conducted a regression analysis of foreign aid in consistent with the economic growth of the Philippines. The OLS regression of the model yielded an adjusted R2 of .634, so $63.4 \%$ of the variation in the dependent variable is explained by the empirical model. The coefficients of all the variables except social aid have the expected signs, and all of them are significant at the 0.05 or 0.01 level. The coefficients of FDI and ODA per capita have a positive impact on GDP growth as expected.

Balcioglu (2016) has conducted a research on the foreign aid and economic growth, a panel cointegrationfor selected Turkic Republics. The study indicates the long-run relationship between foreign aid and real economic growth for the period 1992-2014. It concludes that the Turkish foreign aid has a significant positive impact on economic growth for Azerbaijan, Georgia, Kazakhstan, Kyrgyzstan, Turkmenistan and Uzbekistan. The country-specific elasticity of real income with respect to foreign aid for most of the countries is close to one so it can be recommended that foreign capital flows can have more positive effect on real income with the supplements of domestic savings and complements of domestic resources. So, it is advisable for the considered countries to develop their capacities to optimize the benefits from international resources with supportive integration in international markets.

\section{Research Design}

Newman (2010) demonstrate that the research design depends on the research questions as well as the purpose of study. The research design for this work is descriptive and correlation design. It is descriptive because it will be used to obtain the frequencies, percentages, means, and standard deviations, and correlation because it will help to analyze the relationship between variables.

\subsection{Population of the Study}

Population is the totality of all elements, subjects, or members that possess a specified set of one more common characteristic. Population is the entire set of individuals of interest to a research, (Pamela, 2006). Twenty-two universities in Kigali were beneficially of RCIPRW project activities like WiFi and broadband internet connectivity. The project implementing institution RDB and as well BSC, RISA and MINCOFIN staff are part of the population of this study having their role in the project implementation.

\subsection{Sampling Techniques}

A sample can be defined as a group of subject drawn from the entire population in order to be tested or examined in details and make a generalization later. Sampling is the process of using a small number of items or parts of a larger population to make conclusions about the whole population (Mugenda, 2009). The researcher used purposive and convenience sampling during this study. According to Cohen, Manion \& Morrison (2007) in purposive sampling, 
researchers handpick the cases to be included in the sample on basis of judgment of their typicality or possession of the particular characteristics being sought. They indicated also that convenience sampling involves selecting respondents primarily on basis of their availability and willingness to respond. Purposive sampling have been used to select employees in charge of ICT in higher learning institutions, Broadband Systems Corporation Ltd (BSC Ltd) staff, Rwanda Information Society Authority (RISA) staff, MINECOFIN projects implementation unit staff and Rwanda Development Board single project implementation unit staff. In total 24 employees from these institutions contributed to this research through responding elaborated questionnaire and by the mean of interview. Not only employees participated to the noble course of this research but also students of higher learning institutions were selected and purposively six students responded to the questionnaire.

\subsection{Research Instruments}

In data collection process, the researcher used different types of instruments and specifically primary and secondary instruments of data collections.

\subsubsection{Primary Data}

Questionnaire is primary and main instrument in survey research but also in experiments, field research, and modes of observation. The questionnaire is preferred because the respondents will be free to give answers to the questions. Also it encourages respondents to give open and straight to sensitive questions thus helping the researcher to acquire important information (Hilary, 2009). The questionnaire was formulated in English.

The use of questionnaire involves a list of written questions given to certain category respondents. Before the respondents start to answer the questions, the researcher took time of explaining the questionnaire. The scaling is composed of the following: 1.Strongly disagree (SD), 2.Disagree (D), 3.Neutral (N) 4.Tend to Agree (TA), 5.Agree (A),6.Strongly Agree (SA). The researcher used the below interpretation scale (Hilary, 2009).

Table 1. Interpretation Scale

\begin{tabular}{ll}
\hline Weight Scale & Interpretation of the scale \\
\hline 1 & Strongly Disagree (SD) \\
2 & Disagree (D) \\
3 & Neutral (N) \\
4 & Tend to Agree(TA) \\
5 & Agree (A) \\
6 & Strongly Agree(SA) \\
\hline
\end{tabular}

Source: Hilary (2009)

\subsubsection{The Secondary Data Analysis}

According to Johnston (2014), secondary data is analysis of data that was collected by someone else for another primary purpose. He indicated that the utilization of this existing data provides a viable option for researchers who may have limited time and resources. Beside the questionnaire, the researcher also used the RCIP project information available at RDB and other official websites in order to assess the effective use of funds of RCIP project and project outcomes.

\subsection{Validity and Reliability of Instrument}

\subsubsection{Validity}

Validity is concerned with whether the findings are really about what they appear to be (Robson, 2012). For this study, the researcher, his supervisor and other experts in domain did the validity. The researcher developed structured questionnaire and thereafter looked for advices from the supervisor and expert in project management and ICT.

\subsubsection{Reliability}

Reliability refers to the extent to which your data collection techniques or analysis procedures yield consistent findings (Robson, 2012).

Research requires dependable measurement. Measurements are reliable to the extent that they are repeatable and that any random influence, which tends to make measurements different from occasion to occasion or circumstance to circumstance, is a source of measurement error. Reliability is the degree to which a test consistently measures 
whatever it measures. Errors of measurement that affect reliability are random errors and errors of measurement that affect validity are systematic or constant errors, which are characterized by the pilot study (Vicky, 2012). The coefficient of Cronbach's alpha equal to 0.7 and above accepted as sufficient reliable for the purpose of this study. Conducted pilot study results from 20 persons in charge of ICT and project management helped in measuring reliability of the research instruments.

\section{Results and Discussions}

The World Bank was initiating the Regional Communications Infrastructure Program (RCIP) to support all the countries in Eastern and Southern Africa to improve and integrate the essential utility of telecommunications. Rwanda was included as Phase II with the same aim of decreasing regional and national telecommunications costs, increasing reliability and capacity of the networks, and setting the foundation for improved government efficiency and effectiveness through technology (PAD, RCIPRW Phase 2).

To make the project successful, the management team has been put in place based on the nature of the project and experience background of each individual composing the team. The Team Task Leader (TTL) from the World Bank Group was the overall project manager and locally a Lead Task Manager (LTM) was recruited. The LTM had to recruit suitable candidates to help the best project implementation tasks along the project life. A good team composed of two Internet Broadband Specialist, a Monitoring and Evaluation Specialist, a Procurement Specialist, a Financial Management Specialist, a Communication and Marketing Specialist, Accountant and Administration Officer have been recruited to accomplish the mission of the project (Interview with the LTM). The team had to implement the project activities in accordance with the signed Memorandum of Understanding, the project Financial Agreement, the World Bank Procurement Procedures and the Government of Rwanda Public Finance Management Procedures.

\subsection{Project Financing Components}

The Regional Communication Infrastructure Program was composed of three main components and contingency budget as described in the table below:

Table 2. Project Cost by Component and Activity

\begin{tabular}{|c|c|c|}
\hline Components & Description & Amount in US \$ \\
\hline Enabling Environment & $\begin{array}{l}\text { The component is all about capacity building support to } \\
\text { the agencies and ministries concerned with the project. }\end{array}$ & $2,670,000$ \\
\hline Connectivity & $\begin{array}{l}\text { This component dealt with rollout of the broadband } \\
\text { access networks through the provision of a basic } \\
\text { package of broadband services at low-cost and } \\
\text { connectivity to public institutions across the country. It } \\
\text { financed the purchase of bulk international broadband } \\
\text { capacity on regional and international networks and the } \\
\text { construction of a Virtual Landing. It enabled the } \\
\text { establishment of third party Virtual Landing Station or a } \\
\text { "tele house" }\end{array}$ & $18,000,000$ \\
\hline Project Management & $\begin{array}{l}\text { The component aim was to address all sorts of project } \\
\text { management cost }\end{array}$ & $2,190,000$ \\
\hline Contingency & $\begin{array}{l}\text { Due to volatile ICT equipment cost and fluctuation of } \\
\text { USD over SDR as the project agreement currency, a } \\
\text { contingency budget has been added to cover any deficit } \\
\text { that may arise }\end{array}$ & $1,140,000$ \\
\hline Total & & $\$ 24,000,000$ \\
\hline
\end{tabular}

Source: Secondary data compilation

\subsection{Disbursement and Budget Execution Rate}

The project total cost was made of SDR $15,300,000$ or USD $24,000,000$ allocated to three components with the implementation period of six and half year. Funds disbursement is one key element of the project implementation as it affects either positively or negatively the overall achievements and outcomes of the project given that projects have 
open-end lifespan. The table below presents the RCIP-RW disbursement status and the rate of consumption at the closure of the Project.

Table 3. Project Disbursement

\begin{tabular}{llllll}
\hline Donor & $\begin{array}{l}\text { Amount in } \\
\text { SDR }\end{array}$ & $\begin{array}{l}\text { Equivalent } \\
\text { in US\$ }\end{array}$ & $\begin{array}{l}\text { Executed as of 30th } \\
\text { Sept 2015 in SDR }\end{array}$ & $\begin{array}{l}\text { Execution as of 30th } \\
\text { Sept 2015 in US\$ }\end{array}$ & $\begin{array}{l}\text { Execution } \\
\text { Rate in \% }\end{array}$ \\
\hline World Bank & $15,300,000$ & $24,000,000$ & $15,229,999.5$ & $23,890,195$ & $99.54 \%$ \\
\hline Total & $\mathbf{1 5 , 3 0 0 , 0 0 0}$ & $\mathbf{2 4 , 0 0 0 , 0 0 0}$ & $\mathbf{1 5 , 2 2 9 , 9 9 9 . 5}$ & $\mathbf{2 3 , 8 9 0 , 1 9 5}$ & $\mathbf{9 9 . 5 4 \%}$ \\
\hline
\end{tabular}

Source: OAG Audit Report 2016

From the table above, it is clear that funds allocated to implement components activities in table 1 reached an execution rate of $99.54 \%$ and only 0.46 of the project total cost was not absorbed. Both the bank and the Government of Rwanda satisfactorily appreciated physical and financial performance of the Regional Communication Infrastructure Program. Assuming that all funds commitment have been done according to the project financing agreement, this is of no doubt that all planned activities reached the end target and hence the overall mission of enhancing the ICT sector development of Rwanda accomplished.

The next section is data analysis from questionnaire distributed to $\mathrm{N}$ number equal to 30 people from both public and private institutions. The questionnaire was prepared, distributed and collected after respondents gave their views on both funds management as independent variable and ICT sector development in Rwanda as dependent variable of this research.

\subsection{Evaluation of Funds Management Team and Project Implementation Procedures}

As stated in the previous chapter, donors' fund or foreign aid for the purpose of this study is financial flows, technical assistance, and commodities designed to promote economic development and welfare as their main objective and they are provided as either grants or subsidized loans (Randhawa, 2012).

Funds management team and project implementation procedures is a derivative of many other variables hence it does not exist in isolation. Experiences and observations have shown that the high fund management team, and respect of project implementation procedures as designed, contribute much to the development of the sector being funded and here the ICT sector. RDB put in place skillful and proficient team in managing donors' funds allocated to support Rwanda ICT sector and the end results are that most of expected outcomes have been achieved. This theoretical assumption was investigated through all means and the results qualify that good funds management team and project implementation procedures respect lead to successful achievements.

Table 4. Respondents' Rating on Funds Management Team and Implementation Pro- Cedures

\begin{tabular}{|c|c|c|}
\hline & Mean & SD \\
\hline $\begin{array}{l}\text { The Organization has put in Place a strong team with required skills and mental } \\
\text { capabilities to properly manage granted funds from donor. }\end{array}$ & 5.5333 & .50742 \\
\hline Capacity Building for staff managing donors' funds is ensured and done regularly. & 4.6333 & .99943 \\
\hline A clear road map on the project implementation has been put in place. & 5.5667 & .62606 \\
\hline $\begin{array}{l}\text { Monitoring and evaluation of project activities is conducted on a regular basis and } \\
\text { recommendations are absolutely implemented. }\end{array}$ & 5.5000 & .57235 \\
\hline $\begin{array}{l}\text { Activities implementation reports are provided on time to different stakeholders, } \\
\text { assessed and recommendations executed. }\end{array}$ & 5.3000 & .65126 \\
\hline $\begin{array}{l}\text { Project steering Committee review periodically the general aspects of project } \\
\text { implementation. }\end{array}$ & 3.4000 & 1.77337 \\
\hline Fund management team and project implementation procedures & 4.99 & $\mathbf{0 . 8 3}$ \\
\hline
\end{tabular}

Source: primary data (2018) 
The results from respondents' evaluation on funds management body and as well compliance with activities implementation as presented in table 4.4, was ranked with a cumulative mean of 4.99 ( $\mathrm{SD}=0.83$ ). This imply that characteristics of donors' funds management fulfilment together with proper implementation procedures are in line with ICT sector development through the RCIP-RW project. The average mean of 4.99 is evaluated as very strong and the data homogeneity characterised by a standard deviation of 0.83 shows how closeness fund management team and project implementation procedures interact each other to provide efficient management of donors' funds.

The findings on fund management team and project implementation procedures are complex and fundamental to understanding the dynamics in the public institutions that are profoundly different from the private profit oriented business organizations.

\subsection{Internal Control Enforcement}

Internal control enforcement is one the most discussed and known theories in the management field and from which factors influencing success of donors' funded projects. The divergent findings and conclusions are often anchored internal control enforcements environment as primary determinants of funds management success. Internal controls as part of determinants regulating funds management got surveyed to analyse its effect on the ICT sector development through the regional communication infrastructure program. The results in table 4.5 below show that the rating of internal control enforcement had a cumulative mean of 5.03 and a standard deviation of 0.5 indicating that on the general average the surveyed respondents tend to agree that RCIP-RW project succeeded due to the internal control enforcements in place. The categorical statements on internal control enforcement are presented below.

Table 5. Respondents' Evaluation of Internal Control Enforcement

\begin{tabular}{|c|c|c|}
\hline & Mean & SD \\
\hline All Financial Transactions are verified, certified and approved by authorized individual & 5.9333 & .36515 \\
\hline Accounting records are complete, accurate and books keeping is properly done & 5.7333 & .44978 \\
\hline Accounting policies and procedures put in place by competent authority are respected & 4.9667 & .49013 \\
\hline Budget Commitments follow financing agreement by categories of expenditure & 5.1333 & .34575 \\
\hline $\begin{array}{l}\text { Funds disbursement is done on time without delaying normal process of project } \\
\text { implementation }\end{array}$ & 5.0333 & .66868 \\
\hline $\begin{array}{l}\text { Procurement procedures based on both donors' rules and the procuring entity } \\
\text { procedures in place are followed without any breach }\end{array}$ & 5.0333 & .61495 \\
\hline Financial Statements are produced and submitted on time & 5.3000 & .53498 \\
\hline $\begin{array}{l}\text { An internal audit and as well external audit are carried out on regular basis against } \\
\text { physical and project financial statements }\end{array}$ & 5.4333 & .62606 \\
\hline Internal control enforcement & 5.03 & 0.50 \\
\hline
\end{tabular}

Source: primary data (2018)

The findings from the elements of internal control enforcement as ascribed in above table denote that the respondents rate it high. This implies that, abiding with factors influencing internal control played a major role in RCIP-RW funds management and hence affected good implementation of the project activities and as well achievement of the major target of reducing the international internet broadband capacity connectivity cost. A standard deviation of 0.5 is denoted as all data being nearer the mean of 5.03, which is an indication that the surveyed respondents have the tendency to experience good internal control enforcement as good characteristic of fund management.

\subsection{Respondents Views on ICT Sector Development}

Among various business sectors, Rwanda has promoted the ICT sector based on a mission of building a knowledge-based economy to modernize key sectors by using ICT. The purpose of establishing a knowledge-based economy is to make Rwanda a middle-income country by 2020. Based on this goal, Rwanda has sought to transform the country into an IT-literate nation by promoting deployment and utilization of ICTs, improving infrastructure, transforming educational systems using ICTs, and improving human resource development capacities to meet demands of the economy. In the process, Rwanda has envisioned the country becoming a future regional ICT hub, 
aligning Rwanda with other regional countries while providing its own people and countries with high quality services (Tataki F, 2016).

Beside the literature review where a number of books and journals described the Rwandan ICT sector development, the researcher tried to bring in a new aspect of looking what is the common denominator of this key sector development. The main objective of this study was to analyze the effect of donors' funds management on the Rwandan ICT sector development and based on this lead statement, the researcher compiled different views of officials from both public and private institutions and derived a relationship between both variables of the subject matter of this research.

Analysis of findings from primary and as well secondary data has proved a strong impact of effective donors' funds management on the supported sector. Table 4.6 findings as demonstrated below present respondents views on ICT Sector developments in Rwanda.

The statistical results in the table below with the cumulative mean of $4.17(S D=0.4)$ demonstrate that respondents' perceptions strongly agree that Rwanda ICT sector has tremendously developed. Nevertheless, the rating of each item differs across the total element contributing to the variable of ICT sector development.

Table 6. Respondents' Evaluation of ICT Sector Development

\begin{tabular}{|c|c|c|}
\hline & Mean & SD \\
\hline There have been an apparent development of Rwanda ICT Sector time after time & 5.8667 & .34575 \\
\hline $\begin{array}{l}\text { ICT infrastructure put in place by the government with the support of World Bank } \\
\text { Project boosted up the ICT sector }\end{array}$ & 5.9667 & .18257 \\
\hline $\begin{array}{l}\text { The availability of International Internet Bandwidth lowered the price of volume of } \\
\text { international internet traffic }\end{array}$ & 5.5000 & .68229 \\
\hline $\begin{array}{l}\text { The expansion of internet broadband geographic reach reduced the cost of internet } \\
\text { from private ISP }\end{array}$ & 5.5667 & .56832 \\
\hline $\begin{array}{l}\text { The Wireless Internet Connectivity and as well International Internet bandwidth to } \\
\text { higher learning institutions and Public Institutions uplifted the quality of service } \\
\text { delivery and education quality }\end{array}$ & 5.5333 & .57135 \\
\hline $\begin{array}{l}\text { There have been positive changes in private sector services delivery due to low price } \\
\text { of international internet connectivity }\end{array}$ & 5.7667 & .43018 \\
\hline $\begin{array}{l}\text { Various technologies based on Internet accessibility have been developed at a wide } \\
\text { range speed across the country }\end{array}$ & 5.7000 & .79438 \\
\hline $\begin{array}{l}\text { The number of Internet Service Providers (ISP) and as well subscribers to internet } \\
\text { usage increased }\end{array}$ & 5.7333 & .63968 \\
\hline Users of Internet services are satisfied with both access and cost related & 4.3667 & .85029 \\
\hline The ICT sector development is source of other sectors development & 5.1667 & 64772 \\
\hline $\begin{array}{l}\text { There is a strong relationship between management of funds allocated to ICT sector } \\
\text { and its development }\end{array}$ & 5.9000 & .40258 \\
\hline $\begin{array}{l}\text { Funds mismanagement leads to implementation failure of planned activities and hence } \\
\text { a development handicap }\end{array}$ & 5.9667 & .18257 \\
\hline ICT Sector Development & 4.17 & 0.4 \\
\hline
\end{tabular}

Source: primary data (2018)

From many aspects of ICT sector development as perceived above, infrastructure put in place by the government of Rwanda with the support of the World Bank project boosted up the ICT sector with an affirmative mean of 5.9667 $(S D=0.18257)$. The government of Rwanda focused on high quality communication infrastructures, which encompassed nationwide coverage of telecommunication and fiber networks and the establishment of a national data center. Although a number of fixed telecommunication line subscriptions increased about $10 \%$ during the 
implementation of RCIP-RW and as well NICI II, mobile subscriptions and Internet subscriptions increased $217 \%$ and $1,000 \%$ respectively.

This led to educational reforms and wider ICT usage in public and private sectors transactions. Skills development programs and trainings to professionals and young adults were created to help develop marketable skills by several institutions and mainly the Rwanda Development Board (RDB).

The availability of International Internet Bandwidth lowered the price of volume of international internet traffic and a statistical mean score of $5.5000(S D=0.68229)$ was recorded and elsewhere, the expansion of internet broadband geographic reach reduced the cost of internet from private ISP rated with a mean of $5.5667(S D=0.56832)$ among the surveyed respondents.

According to the World Bank report (ICR,2015), the combined effects of the Government's prior capacity purchases plus the project financed capacity purchases and construction of the Virtual Landing Station led to a surpassing of the project's targets for the expansion of broadband access. Teledensity in the country exceeded 70 percent at the end of the project from a baseline of 10 percent and far outperformed the target of 15 percent.

Below table gives the real trend of how radical change in international internet capacity cost from $\$ 10,000$ in 2008 up to $\$ 125$ in 2014.

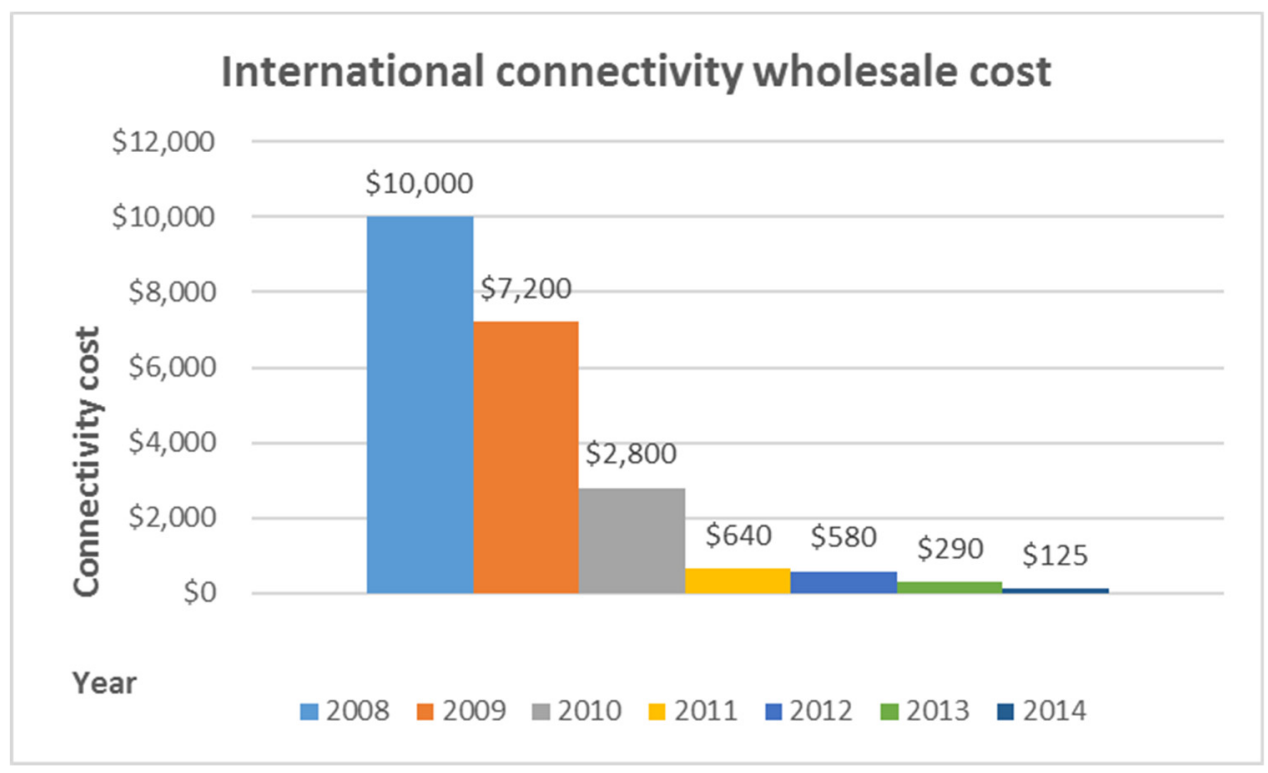

Figure 1. International Connectivity Wholesale Cost

Source: Primary data compilation (ICR, 2015)

Due to the up down fall in international connectivity cost, the number of broadband subscribers grew from 726 in 2009 to an astonishing 2.5 million in 2015. The international Internet volume of traffic reached 11,684 mbits/second, grossly exceeded its target of $600 \mathrm{mbits} / \mathrm{second}$. The project originally targeted 700 institutions including schools, local government offices and health clinics, for broadband access. It exceeded this target in 2015 and continued to connect 783 in total, either through Wi-Fi access points or through the Rwanda Online telecenters (World Bank Report, 2015).

It is obviously clear that fund from donors and especially the World Bank project played a key role in financing the Rwanda ICT sector development. Not all these achievements could have been reached with the absence of effective funds management. Commitments of funds to respective activities is the first step to achieve predetermined outcomes. Lack of effective and efficient funds management results in failure and abasement of sector development.

\subsection{Relationship between Donor's Fund and ICT}

The aim of correlation analysis was to measure the strength and closeness of the relationship between independent variable to dependent variable and for the case of this study, donors fund management to ICT sector development. 
Table 7. Donors' Funds Management and ICT sector Development Variables Corre-Lation

\begin{tabular}{lllll}
\hline & & $\begin{array}{l}\text { Donors fund ICT } \\
\text { management }\end{array}$ & $\begin{array}{l}\text { Sector } \\
\text { Development }\end{array}$ & \\
\hline Donors fund management & Pearson Correlation & 1 & $.814^{* *}$ \\
& Sig. (2-tailed) & & .000 \\
& $\mathrm{~N}$ & 30 & 30 \\
ICT Sector Development & Pearson Correlation & $.814^{* *}$ & 1 \\
& Sig. (2-tailed) & .000 & \\
& $\mathrm{~N}$ & 30 & 30 \\
\hline
\end{tabular}

$.814 *$ Correlation is significant at the 0.01 level (2-tailed).

Source: Primary data (2018)

Table 7, gives a Pearson correlation coefficient between the determinants of donors fund Management and ICT sector development. The sample size $\mathrm{N}$ is 30 and the significant level is 0.01 . The statistical evidence depict that there is a significant relationship between donors fund management and ICT sector development represented by $\mathrm{r}=0.814^{* *}$ (positive high correlation). The $\mathrm{P}$ value is 0.000 which is less than 0.01 , when p-value is less than significant level, it means that the variables are correlated this merely implies that donors fund management influenced the ICT Sector Development within Regional Communication Infrastructure Program, Rwanda-Project.

\section{Conclusion and Recommendations}

The study found that wherever there is proper financial management and especially donors' funds management that come in line with supporting Government economic sector development, perfect outcomes might be observed. The inverse is that any missuses or misallocation of funds may lead to poor economic sector development. The Regional Communication Infrastructure Program was conceived and implemented with the sole aim of boosting the Rwandan ICT sector development. This happened after reports showed that Rwanda Teledensity remained below the normal percentage of 19 compared to other Sub-Saharan countries. The Ministry of finance and economic development together with the office of the auditor general's reports, have been always raising a red flag on donors' funds management whereby a number of donors' funds have been returned after projects effective closure date. This raised the researcher's attention to reveal what effect effective donors' funds management can contribute on the economic sector funded and in this case, the ICT sector development.

The researcher profoundly noted that not only satisfying donors and keeping good relationship with them come from effective management of their funds, but also the economic sector development as concerned. The Regional Communication Infrastructure Project budget was efficiently managed and an effective funds management was noted since the beginning to the end of the project. Audit reports from the auditor general's office resulted from audits against RCIPRW financial statements from the year 2010 to 2015 and they were always clean. The researcher also noted satisfaction from the World Bank through mid-term and implementation completion reports.

Respondents views on both variables of the research subject and as analyzed by mean of statistical data, outcomes show high correlation of both of them donors' funds management and ICT sector development.

Recommendations are formulated as follow: (1) As previously highlighted, donors' funds main purpose is to supplement government's activities through services delivery. Whatever style of management used to absorb given package of funds, donors' expectations are compliance with rules and procedures put in place to execute fund commitment and as well activities implementation targeting the economic sector beneficiaries. Proper funds management as engine of economic sectors development is extremely recommended to make sure underutilization, embezzlement of funds, misallocation and funds deviation are avoided. (2) Factors such as recruitment of suitable candidates and capacity building of staff managing donors' funds is highly recommended given that any deviation from both of them may disfavor projected outcomes. (3) Timely and accurate financial statements are to be prepared and officially disclosed as tools for monitoring and controlling funds execution level and as well activities implementation. (4) Internal controls enforcement and as well monitoring and evaluation functions are key tools in measuring physical and financial performance of donors' funded projects and they have to be active to make healthier the whole process of implementation. (5) Notwithstanding with the researchers findings, many other areas of the topic might be explored to make it more useful not only to readers but also to the public and private donors' 
funds managers and especially to contribute to the best extent possible in donors' funds management and economic sectors development.

\section{References}

Abouraia, M. K. (2014). The impact of foreign aid in economic development of developing countries: A case of Philippine. European Journal of Business and Social Sciences, 3(4), 2235-767X.

Addison, T., Niño-Zarazua, M., \& Tarp, F. (2015). Aid, social policy and development. Journal of International Development, 1351-1365. https://doi.org/10.1002/jid.3187

Afande, O.F. (2013). Factors affecting use of donor aid by international non-governmental organizations in Kenya: A case of USAID. International Journal of Business Management and Administration, 2(5), 2327-3100.

Andrews, N. (2009). Foreign aid and development in Africa: What the literature says and what the reality is. Journal of African Studies and Development, 1(1), 8-015.

Asian Development Bank (2006). Handbook for borrowers on the financial management and analysis of projects. Retrieved from: https://www.adb.org/sites/default/files/.../31339/financial-governance-management.pdf

Balcioglu, H. (2016). Foreign aid and economic growth, a panel cointegration for selected Turkic Republics. International Journal of Business and Social Research, 6(6). https://doi.org/10.18533/ijbsr.v6i6.947

Bernard, R. H. (2006). Research methods in anthropology: Qualitative and quantitative approaches (4 ${ }^{\text {th }}$ Ed.). Oxford, UK, AltaMira Press

Blake, M., \& Garzon, Q. (2010). ICT for Development: sustainable technology-supported participatory development for poverty alleviation in the context of digital divides, Term paper presented to the Center for Development Research, University of Bonn. Retrieved https://www.zef.de/fileadmin/downloads/forum/docprog/Termpapers/2010_1_Blake_Quiros.pdf

Booth, D. (2011). Aid effectiveness: bringing country ownership (and politics) back in. Oversea Development Institute working paper, 336, 1759-2917.

Caccavale, J., Haver, K., \& Stoddard, A. (2016). Donor Reporting Requirements Research. Humanitarian outcomes. Retrieved

from: https://www.ghdinitiative.org/assets/files/Activities/Our\%20Work/Research\%20on\%20donor\%20reporting\%20 requirements_22\%20Feb\%20FINAL.pdf

Center for Democracy and Technology. (2002). Bridging the Digital Divide report. Retrieved from: http://www.cdt.org/international/ceeaccess.

Cohen, L., Manion, L., \& Morrison, K. (2007). Research methods in education (6th Ed.). New York, NY, Routledge. https://doi.org/10.4324/9780203029053

Delponte, L., Grigolini, M., Moroni, A., Vigneti, S., Claps, M., \& Giguashvili, N. (2015). ICT in developing World, European Parliament. https://doi.org/10.2861/52304

Ekanyake, E. M., \& Chatrna, D. (2010). The effects of foreign aid on economic growth in developing countries. Journal of International Business and Cultural Studies, Retrieved from: https://www.researchgate.net/publication/255605340_The_effect_of_foreign_aid_on_economic_growth_in_dev eloping_countries

EURODAD (2009) Procurement and Development Effectiveness: A literature review commissioned by EURODAD. Retrieved from: www.eurodad.org/../literature\%20review\%20procurement $\% 20$ and $\% 20$ development

Ferrro, V. (1996). Dependency theory: An introduction. Retrieved from semanticscholar.org/d715/82f1a87a914036b3af3696b2be5e8411a7c8.pdf

Goswami, K.M. (2016). The impact of foreign aid in economic development of India, International Journal of Pure and Applied Researches, 3(1), 2455-474X.

Hilary (2009). Research Methods in Social Relations. Boston: Harvard Business School Press.

Hossain, B. (2014). The Effect of Foreign Aid on the Economic Growth of Bangladesh. Journal of Economics and Development Studies, 2(2), 2334-2390.

International Development assistance (2009) Rwanda: From Post-Conflict Reconstruction to Development. Retrieved 
from siteresources.worldbank.org/IDA/Resources/ida-Rwanda-10-02-09.pdf on 24/04/2016

ITU (2013) Internet exchanges points (IXPs), WTPF Backgrounder series. Retrieved from: https://www.itu.int/en/wtpf-13/Documents/backgrounder-wtpf-13-ixps-en.pdf on 06/05/2017

ITU (2014) New telecommunication/ICT indicators from administrative data sources. Retrieved from: https://www.itu.int/dms_pub/itu-d/opb/ind/D-IND-ITC_IND_HBK-2011-C1-PDF-E.pdf

ITU (2016) Core list of ICT indicators. Retrieved from: https://www.itu.int/en/ITU-D/.../coreindicators/Core-List-of-Indicators_March2016.pd

Johnston, M. P. (2014). Secondary Data Analysis: A Method of which the Time Has Come. Qualitative and Quantitative Methods in Libraries (QQML), 3, 2241-1925.

Keng'ara, R. (2014). Effect of Funds Disbursement Procedures on Implementation of Donor Projects in Homabay County, Kenya. Universal Journal of Accounting and Finance, 2(2). https://doi.org/10.13189/ujaf.2014.020102

Kerzner, H. (2009). Project management: A systems approach to planning, scheduling and controlling ( $9^{\text {th }}$ Ed.), Hoboken, New Jersey, John Wiley \& Sons

Koenig, A. N., \& Jackson, E. T. (2016). Private Capital for Sustainable Development: Concepts, Issues and Options for Engagement in Impact Investing and Innovative Finance. Evaluation report presented to the Ministry of Foreign Affairs of Denmark and DANIDA. Retrieved 10/05/2017 from: www.netpublikationer.dk/um/evaluation_study.../Pdf/evaluation_study_2016_02.pdf

Larson, E. W., \& Gray, C. F. (2011). Project management: The managerial process (5 ${ }^{\text {th }}$ Ed.). New York, NY, McGraw-Hill

McDonald, O. (2016). Government procurement, development and World Bank conditionalities, G-24 Policy Brief No. 20, accessed from: https://www.g24.org/wpcontent/uploads/2016/01/G24-Policy-Brief-20.pdf

Mefteh, H., \& Benjassen, L. (2015). Impact of Information Technology and Communication on Economic Growth. International Journal of Economics, Finance and Management, 4(2), 2307-2466.

Ministry of Finance and Economic Planning (2006) Rwanda aid policy. Retrieved from www.moh.gov.rw/fileadmin/templates/protocols/Rwanda_Aid_Policy.pdf on 24/04/2017

Mugenda, O. (2009). Research Methods: Quantitative and qualitative. Makelele, university, Kampala.

Newman, E. (2010). Research Methods: Quantitative and Qualitative Approaches. Nairobi.: Acts Press.

Njeru, J. (2003). The impact of foreign aid on public expenditure: The case of Kenya. African Economic Research Consortium Research paper 135, Retrieved from dspace.africaportal.org/jspui/bitstream/123456789/32372/1/rp135.pdf on 28/04/2017

OECD (2003) Harmonizing Donor Practices for Effective Aid Delivery: DAC guidelines and reference series. Retrieved from: https://www.oecd.org/dac/effectiveness/20896122.pdf

OECD (2005) The Paris declaration on aid effectiveness and the Accra agenda for action, Retrieved 27/04/2017 from: www.oecd.org/dac/effectiveness/34428351.pdf

Ojuloge, B., \& Awoleye, M. O. (2012). Analysis of Internet Diffusion and Adoption in Selected Afrcan Countries. International Journal of Internet of Things, 1(3). https://doi.org/10.5923/j.ijit.20120103.01

Pamela, O. (2006). Research Methods for Business and Social Studies. Nairobi: Mzumbe.

Paramasivan, C., \& Subramanian (nd). Financial management. New Delhi, New age International.

Patton, M. Q., \& Foote, N. (2015). A Foundation's Theory of Philanthropy: What It Is, What It Provides, How to Do I. The foundation review, 7(4). https://doi.org/10.9707/1944-5660.1263

Randhawa, G.K. (2012). Foreign aid in economic development. International Journal of Computing \& Business Research, 2229-6166.

Republic of South Africa (2005). Financial management of projects, Water Affairs \& Forest, Retrieved from: webapps.daff.gov.za/.../PFM\%20Guideline4Financial\%20Management\%20of\%20r

Robson (2012). Research Methodology in Business and Social science. Owerri: Canum.

Rodriguez, F., \& Wilson, E.J. (2000) 'Are Poor Countries Losing the Information Revolution' Info Dev Working Paper, May 2000. University of Maryland at College Park. 
Sanders \& Smith (2012). Simple random sampling techniques. New York: Academic Press.

SNV (n.d) Innovative Finance for Renewable Energy Solutions, Retrieved from: www.snv.org/public/cms/sites/default/files/explore/.../innovative_finance.pdf

Tataki, F. (2016). Human Capital Development for Small and Medium Enterprises, The case study of Rwanda, the Fletcher School, Tufts University.

United Nation Conference on Trade and Development (2003) Information and Communication Technology development indices. Retrieved from: unctad.org/en/docs/iteipc20031_en.pdf

Vanberg, M. A. (2009). Competition and Cooperation in Internet Backbone Services. Paper of Centre for European Economic Research. https://doi.org/10.1007/978-3-7908-2082-9_3

Vicky (2012). The Art and Science of Learning from Data, Upper Saddle. River, NJ: Prentice Hall.

Williamson, C.R. (2009). Exploring the failure of foreign aid: The role of incentives and information. Rev Austrian Econ., 23(1), 17-33. https://doi.org/10.1007/s11138-009-0091-7

World Bank (2008) Financing Agreement, Regional Communications Infrastructure Program (Phase 2): Rwanda Project. Retrieved 25/04/2017 from: docments.worldbank.org/curated/en/.../pdf/FA01Conformed1.pdf

World Bank, OECD \& WHO (2008). Effective aid: Better Health, Report prepared for the Accra High Level Forum on Aid Effectiveness. Retrieved from: www.who.int/hdp/publications/effectiveaid_betterhealth_en.pdf 